\title{
EVALUATION OF THE IMPACT OF SELF-EMPLOYMENT FACTORS ON SELF-EMPLOYMENT DURATION IN THE COUNTRY WITH TRANSITION ECONOMY: A LITHUANIAN CASE
}

\author{
Gražina STARTIENĖ, Rita REMEIKIENE \\ Faculty of Economics and Management, Kaunas University of Technology, \\ Laisves al. 55, LT-44309 Kaunas, Lithuania
}

Received 24 August 2012; accepted 01 December 2012

\begin{abstract}
The focus of this article is the factors of self-employment duration having the bidirectional effect (positive or negative) on a self-employed person. The research of the impact of bidirectional self-employment factors on self-employment direction has been encouraged by several reasons. Firstly, the scientific literature lacks of the research to focus on the factors motivating self-employment sustainability. The more abilities a person has to sustain self-employment activity, the more benefits he brings to the country (GDP creation, increase of employment, taxes paid) and his personal environment (ensured material well-being, good psychological state, realized objectives). Secondly, realising the impact of self-employment factors on self-employment duration, the government of the country can start application of the targeted business regulation measures that can help to increase the employment rate in the country. Using the methods of expert evaluation and correlation analysis, the impact of the highlighted self-employment factors on self-employment duration in the country with transition economy (Lithuanian case) has been evaluated: self-employment development is positively influenced by financial and non-financial business promotion measures, decreasing gross domestic product (GDP), extraversion, low level of neuroticism, openness, younger people, education andmarital status defined by having older children; it is negatively influenced by inflexible labour market, high unemployment rate, high income taxes and the immigrants. The article highlights the specificity of the country with transition economy considering the fact that business environment conditions in such countries are more difficult than in industrial countries.
\end{abstract}

Keywords: bidirectional factors of self-employment, self-employment duration, the country with transition economy, self-employment.

Reference to this paper should be made as follows: Startienè, G.; Remeikiene, R. 2013. Evaluation of the impact of self-employment factors on self-employment duration in the country with transition economy: a Lithuanian case, Technological and Economic Development of Economy 19(1): 125-140.

JEL classification: L26, E24.

Corresponding address:

R. Remeikienė E-mail: rita.remeikiene@ktu.lt 


\section{Introduction}

According to Ciemleja and Lace (2011), "Small and medium enterprises are socially and economically important for their national economies because they make about 99 per cent of all enterprises functioning in the European Union. An enterprise, as the base of any economic system, has significant effect on sustainable development of the country or region." (p. 509). With reference to Petuskiene and Glinskiene (2011), "entrepreneurship, as the act of organizational renewal and innovation creation, is the base engine of economy and development" (p. 74). Although self-employment, as the simplest form of entrepreneurship, earned more scientific attention back to 1970-1980, when the number of the self-employed was significantly increasing (Startiene et al. 2010), the impact of self-employment factors on self-employment process (start-up and duration) has still been discussed. The research revealed that in both transition economies and industrial countries, scientists mostly analyse the impact of self-employment start-up factors, i.e. the factors that determine personal decision to act independently in the labour market (Earle, Sakova 2000; Andersson, Hammarstedt 2010; Blanchflower 2008; Leoni, Falk 2010; Krasniqi 2009; Golpe, Stel 2007; Glocker, Steiner 2007; Kim 2007; Oganisjana, Koke 2012; Snieska, Venckuviene 2011; Alvarez-Herranz et al. 2011; Smaliukiene et al. 2012; Moreno et al. 2010; Vázquez-Burgete et al. 2012 and others), whereas the factors of self-employment duration as well as their impact on self-employment level are hardly covered in the scientific literature.

The results of the research of the impact of self-employment factors revealed that the impact of self-employment factors can be bidirectional, i.e. self-employment factors can influence a self-employed person both positively and negatively. For instance, in the group of the factors of institutional environment of self-employment,particular programmes are used to promote (self) employment (Berzinskiene, Juozaitiene 2011). However, these programmes do not ensure the success of business sustainability. Evaluation of the impact of promotional programmes on self-employment duration could help to project targeted measures in order to ensure business sustainability.

It can be assumed that evaluation of the impact of self-employment factors on a self-employed person can help the particular institutions of the country to apply targeted business regulation measures that would promote the increase of self-employment and help to avoid negative consequences on the economy of the country (alternative use of the financial support initially projected for business start-up).

The main problem we meet in the scientific literature is how do self-employment factors influence self-employment duration in transition economies? Transition economies were chosen for the research due to the following reasons: firstly, the conditions of business startup and development are more difficult in transition economies than in industrial countries (European Bank for Reconstruction and Development 2010), and secondly, according to Eurostat data, the number of the self-employed is bigger in transition economies (Hungary, Poland, Lithuania, etc.) in comparison with industrial countries (for example, France or Germany).

The authors are aiming to determine the impact of bidirectional factors of self-employment on self-employment duration in the country with transition economy in this paper. To reach 
the aim expert evaluation, systematical, logical and comparative analysis of the scientific literature and statistical data, correlation analysis are applied in this article.

With reference to the results of the research, in the first part of the article, the bidirectional factors of self-employment duration in each group of self-employment factors have been highlighted and the hypotheses have been formulated. In order to determine the impact of self-employment factors, the second part of the article is designed for the research of the impact of bidirectional factors of self-employment on self-employment duration applying particular methods, i.e. correlation analysis has been used to research the quantitative effects of self-employment factors, and the method of expert evaluation has been used to research the qualitative effects.

\section{Review of literature}

Previous studies revealed that self-employment factors can be classified into particular groups: demographical factors (Startiene, Remeikiene 2009); cultural factors and factors of economic environment (Remeikiene, Startiene 2008); factors of institutional environment (Remeikiene, Startiene 2011); social-psychological factors (Remeikiene et al. 2011). The scientific literature states that apart from the impact of the factors mentioned above, self-employment duration is also influenced by geographical and technological factors. However, the focus of this article is the factors of economic and institutional environment as well as demographical factors having the biggest influence on self-employment duration. On the other hand, some authors (Tervo, Haapanen 2009; Wennekers et al. 2002; Goey 2004; Acs 2008), who analysed geographical and technological factors of self-employment, did not find anybidirectional effects of these factors on self-employment process.

The scientific literature includes many contradictions concerning the impact of self-employment factors on self-employment duration. The results of some studies showed that the same factor in the particular group of self-employment factors can influence a self-employed person positively, but the results of other studies propose converse conclusions. The self-employment factors having bidirectional effect on self-employment duration have been systematised and presented in Table 1 .

Summarizing, it can be concluded that scientists propose contradictory opinions concerning the impact of the analysed factors on self-employment duration. They disagree on which age interval is the most favourable for self-employment development. Higher education can both a bit increase the opportunities to find a salaried work and help to handle business risk, this way sustaining self-employment. The results of previous experience of self-employment can positively or negatively influence self-employment duration. Marital status, especially if a family is growing up children, can become a strive to improve family life standards, but on the other hand, childcare can leave too little time for self-employment development. Immigrants often lack of the experience to develop self-employment in a host country, but on the other hand, the barriers of self-employment development can be overcome learning the local language and knowing the local culture, customs, etc. better. High unemployment rate can reduce self-employment sustainability due to consumption decrease. However, limited opportunities to find a wage employment can become a perfect alternative to make livelihood. 
Table 1. Elaboration of the impact of bidirectional factors of self-employment on self-employment duration

Demographical factors

Age
Georgellis et al. 2007; Praag 2003;
Georgellis et al. 2005;
Holtz-Eakin et al. 1994;
Parker 2004.

Positive effects ("+"):

Professional experience, self-reliance and capital accessibility grow with the age which makes self-employment activity sustained. The older is the person who starts-up self-employment, the longer he performs it because self-employment becomes a perfect alternative after retirement, i.e. the experience and competence are used effectively, maintaining skills and financial stability. Self-employment is sustained when it is led by a middle aged person. Young people can also develop business perfectly because they have not started their families, so their choice has not been influenced by other factors (for instance, maintenance of children or parents).

Negative effects (“-“):

Middle aged people have already started their families and reached the top of career which can reduce the opportunities to start self-employment from scratch seeking for a new recognition. The youth, although being inclined to assume higher business risk, neither have enough financial resources to develop business nor possess the experience of an entrepreneur. People who have reached a ripe old age are less inclined to risk, start-up business and manage it.

Education
Henley 2005; Ritsilä, Tervo 2002;
Bergmann, Sternberg 2007;
Evans, Leighton 1989;
Cowling, Taylor 2001;
Wagner, Sternberg 2004;
Demirgüc-Kunt et al. 2007;
Georgellis et al. 2005;
Georgellis et al. 2007;
Thomas 2009; Falter 2001;
Taylor 1999;
Kangasharju, Pekkala 2002;
Parker 2004.

Positive effects ("+"):

People with higher education are treated as more successful entrepreneurs than other market participants because they have acquired bigger human capital, are able to handle business risk, faster perceive labour market conditions and stay in business longer using their competence. What is more, people with higher education are capable of finding and recognising more profitable market opportunities and information. So higher education enables self-employment sustainability.

Negative effects (“-”):

Education slightly correlates with business sustainability since not all business spheres (for instance, agriculture, particular services, wholesale, and production) require higher education. Education increases the level of human capital which not only enables self-employment sustainability but also opens more opportunities to earn more doing a salaried work.

Positive effects (“+"):

Previous experience

of self-employment

Georgellis et al. 2007;

Joona, Wadensjö 2008;

Falter 2001.
Successful previous experience of self-employment is one of the most important factors, determining self-employment sustainability.

Negative effects (“-"):

Unsuccessful previous experience of self-employment can be a psychological barrier which will remind a person that he can fail again. 
Continued Table 1

Demographical factors

Marital status, defined by marriage Positive effects ("+"):

\section{and children}

Borjas 1986; Williams 2004;

Georgellis et al. 2007

If both spouses are self-employed, it is likely that they will perform their activities longer seeking for the common financial well-being. Children become "a motive" to start-up self-employment.

Negative effects (“-"):

If one of the spouses switches to wage employment (Georgellis et al. 2007), the probability of self-employment sustainability is lower. Having of small children also reduces self-employment duration considering the fact that self-employment is often related to risk, and no one is inclined to risk at the expense of family. In general, childcare negatively influences self-employment duration, although this tendency has not been noticed in all countries.

Immigrants

Ahn 2009;

Clark, Drinkwater 2010

Positive effects (“+"):

Eventually (usually after a year of self-employment performance), immigrants learn the local language and legal regulations which reduces the barriers to develop self-employment.

Negative effects (“-"):

Weak position in labour market, ignorance of industry particularities and the lack of self-employment experience are significant factors explaining inability of national minorities and people of different race to sustain their activities in comparison with local entrepreneurs. The children of the immigrants neither are inclined to start-up self-employment nor help their parents develop it.

The factors of economic environment

Unemployment rate

Golpe, Stel 2007;

Verheul et al. 2006;

Thurik et al. 2008;

Parker 2004; Johansson 2000;

Muehlberger 2007;

Glocker, Steiner 2007.
Positive effects (“+"):

High unemployment rate reduces possibilities to find paid employment (Golpe, Stel 2007), so this way an individual is motivated to become self-employed and develop his activity.

Negative effects (“-“):

High unemployment rate negatively influences individual expectations of self-employment.

Positive effects ("+"):

Higher GDP can show the level of rising economics which disproportionately positively influences the level of self-employment.

Negative effects (“-“):

High level of GDP in the country can determine lower number of the self-employed because there are more opportunities to find paid employment. 
Continued Table 1

\begin{tabular}{|c|c|}
\hline \multicolumn{2}{|l|}{ Demographical factors } \\
\hline \multirow{4}{*}{$\begin{array}{l}\text { Tax tariffs } \\
\text { Briscoe et al. 2000; } \\
\text { Bruce, Mohsin 2006; } \\
\text { Gentry, Hubbard 2000; } \\
\text { Schuetze 2000; Bruce 2000; } \\
\text { Cullen, Gordon 2002; } \\
\text { Fairlie, Meyer 2000. }\end{array}$} & Positive effects ("“+"): \\
\hline & $\begin{array}{l}\text { Positive effects can be caused by high or low income tax tariffs, } \\
\text { i.e. high tax tariff makes a person to choose self-employment } \\
\text { instead of a paid employment due to more opportunities to hide } \\
\text { taxes and so increase self-employment profit; low tax tariff opens } \\
\text { more financial opportunities to develop self-employment. }\end{array}$ \\
\hline & Negative effects ("“-"): \\
\hline & $\begin{array}{l}\text { Negative effects appear when high income taxes and the com- } \\
\text { plexity of the tax system disturb self-employment development. } \\
\text { High taxes "deprive" self-employment of higher profit. }\end{array}$ \\
\hline
\end{tabular}

The factors of institutional environment

\begin{tabular}{|c|c|}
\hline Promotion programmes & Positive effects ("+"): \\
\hline $\begin{array}{l}\text { Dawson et al. 2009; } \\
\text { Noorderhaven 2004; } \\
\text { Hundley 2006; }\end{array}$ & $\begin{array}{l}\text { Promotion programmes enable self-employment sustainability } \\
\text { in the market. }\end{array}$ \\
\hline Plougmann 1998; & Negative effects (“-"): \\
\hline
\end{tabular}

Promotion programmes do not guarantee self-employment sustainability because they usually support the jobless who lack of motivation and the competence necessary for self-employment development.

\begin{tabular}{|c|c|}
\hline \multirow{3}{*}{$\begin{array}{l}\text { Strict regulation of labour market } \\
\text { Djankov 2009; Grubb, Wells 1993; } \\
\text { Carrasco, Ejrnæs 2003; } \\
\text { Verheul et al. } 2001 .\end{array}$} & Positive effects ("+"): \\
\hline & $\begin{array}{l}\text { In the countries with strict labour market regulation, enterprises } \\
\text { (employers) are inclined to use the services provided by inde- } \\
\text { pendent contractors, agents or self-employed people because } \\
\text { this helps to escape the restrictions of recruiting an employee. }\end{array}$ \\
\hline & Negative effects (“-“): \\
\hline
\end{tabular}

High level of corruption and black economy cause the increase of the number of the self-employed.

Psychological factors

Neuroticism, extraversion, openness Singh, DeNoble 2003;

Ciavarella et al. 2004;

Zhao, Seibert 2006.

\section{Positive effects (“+"):}

The "Big Five" structure ${ }^{1}$ includes the personality attributes distinguishing entrepreneur's personality from other personalities.

Negative effects (“-"):

The results of the empirical research revealed the negative impact of the personality attributes mentioned above.

1 The „Big Five” personality attributes toextraversion, emotional stability, agreeableness, conscientiousness, and openness to experience provide the measures of the entrepreneur's personality“. (Ciavarella et al. 2003) 
Growth of GDP shows the rise of the economics in the country and determines increased consumption which positively influences self-employment duration. However, rising economics opens more opportunities to find a wage-job as a paid employee (Golpe, Stel 2007). In many cases, low income tax tariffs increase the profits earned by a self-employed person while high tax tariffs reduce it. On the other hand, a self-employed person can be inclined to hide high income taxes. Promotion programmes can only partly increase the number of the self-employed since they do not guarantee self-employment sustainability. On the other hand, promotion programmes help a person to stay in the market or encourage him to look for new opportunities to export the goods / services to new markets. Strict regulation of labour market can partly contribute to the increase of the number of the self-employed, but it can also reduce the motivation to become an employer hiring other people. In contrast to the "Big Five" structure, where extraversion, openness and neuroticism are considered to distinguish entrepreneur's personality from other personalities, the empirical research has revealed that the impact of the psychological factors on self-employment is different because openness, neuroticism and extraversion suppress self-employment.

After the establishment of bidirectional factors of self-employment duration, and evaluation of the specificity of transition economies, the following hypotheses have been framed:

$1^{\text {st }}$ hypothesis: Self-employment duration is positively influenced by successful previous experience of self-employment, middle aged people, education and having of older children, and negatively influenced by younger people and immigrants (national minorities, people of other race).

$2^{\text {nd }}$ hypothesis: Growth of unemployment rate during the period of economic declineshortens self-employment duration.

$3^{\text {rd }}$ hypothesis: Growth of GDP in transition economies causes the level of self-employment to decrease and self-employment duration to shorten.

$4^{\text {th }}$ hypothesis: Transition economies show the negative link between income taxes and the level of self-employment, i.e. low income taxes prolong self-employment duration while high taxes shorten it.

$5^{\text {th }}$ hypothesis: Strict regulation of labour market is one of the main barriers to develop self-employment in transition economies.

$6^{\text {th }}$ hypothesis: In transition economies, self-employment duration is positively influenced by the increased supply of business promotion measures (financial and non-financial), but lack of information remains the main obstacle to choose the most suitable promotion measure from all possible alternatives and absorb the support.

$7^{\text {th }}$ hypothesis: The self-employed people show low level of neuroticism as well as high level of extraversion and openness.

\section{The results of the empirical research}

For verification of hypotheses 1, 2 and 4-7, the qualitative method of the research was chosen - the research was carried out using the method of expert evaluation by the questionnaire prepared in advance. For verification of hypothesis 3, the quantitative method of the research - correlation analysis - was chosen. The empirical research was based not on the mass 
of the questionnaire survey, but on the competence of the experts, years of their experience in self-employment and the knowledge of self-employment environmental conditions and problems. Therefore, 30 people were included in the group of the experts. The research was carried on in January - February, 2011. The calculated value of Cronbach's alpha ${ }^{2}$ coefficient is equal to $\mathbf{0 . 7 0 6}$, which proposes that the statements of the questionnaire reflect the target value with sufficient accuracy.

Summarizing the answers of the experts, it can be concluded that:

1) $\mathbf{1}^{\text {st }}$ hypothesis was only partly confirmed. More than a half of all the experts agree that self-employment duration is positively influenced by successful previous self-employment experience (as it was stated by 93.4 per cent of the experts), middle aged people (63.4 per cent), education (56.7 per cent) and having older children (70 per cent). The results of the research revealed that younger people is not considered to be an obstacle to develop self-employment since 63.4 per cent of the respondents disagree with this proposition. Evaluating the impact of immigration on self-employment, it was established that 26.7 per cent of the respondents disagree, 30 per cent have no opinion, and 43.3 per cent agree with the proposition that immigrants, national minorities and people of other race stop self-employment activities more often than the local self-employed due to the lack of language skills, ignorance of traditions, business or legal framework. Therefore, immigration can be considered the factor reducing self-employment duration.

2) $2^{\text {nd }}$ hypothesis was only partly confirmed: growth of unemployment rate during the period of economic decline shortens self-employment duration. 43.3 per cent of the experts agree that unemployment rate shortens self-employment duration, 33.3 per cent have no opinion while 23.4 per cent of the experts disagree with this proposition.

3) $4^{\text {th }}$ hypothesis was confirmed because 93.7 per cent of the experts concurred:the negative link between income tax and the level of self-employment is pre-dominant in transition economies, i.e. low taxes prolong self-employment duration while high taxes shorten it.

4) $5^{\text {th }}$ hypothesis was confirmed: strict regulation of labour market is one of the main obstacles to develop self-employment in transition economies. 90 per cent of the experts noted that strict labour market regulation in Lithuania is one of the main barriers for the self-employed to become employers.

5) $6^{\text {th }}$ hypothesis was confirmed: self-employment duration in transition economies is positively influenced by the increased supply of business promotion measures (financial and non-financial), but the lack of information remains the main obstacle to choose the most suitable promotion measure from all possible alternatives and absorb the support. The positive effects of financial business promotion measures were stressed by 96.7 per cent of the experts, and 86.6 per cent agreed that non-financial business promotion measures positively influence self-employment duration. 76.6 per cent of the respondents agreed that the lack of information can determine inability of a self-employed person to choose the business promotion measure, most suitable for his/her activity.

Is based on the correlation of particular questions included in the questionnaire, evaluates whether all questions on the scale reflect the researched value with sufficient accuracy, and enables itemization corrections in particular scale. 
6) According to the experts, a self-employed person must show low level of neuroticism (as it was stated by 96.6 per cent of the experts), high level of extraversion (90 per cent of the experts) and openness (93.3 per cent). This confirms $7^{\text {th }}$ hypothesis.

Distribution of the experts' answers concerning the impact of the factors pointed in hypotheses 1, 2 and 4-7 on self-employment duration is presented in Figures 1-2.

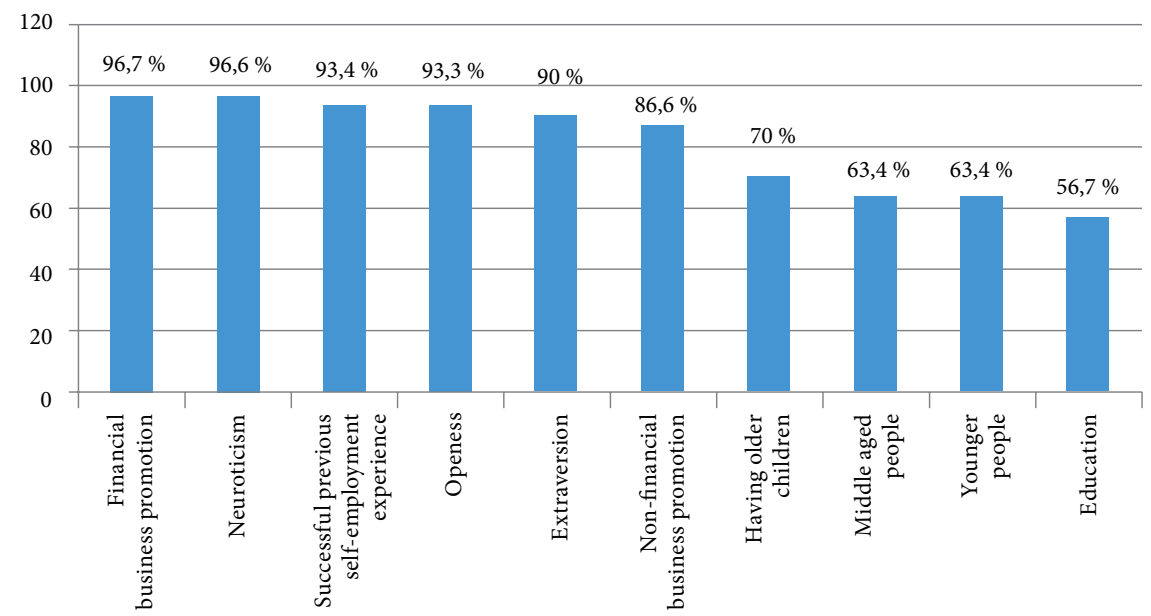

Fig. 1.The factors positively influencing self-employment duration (percentage of the approving experts)

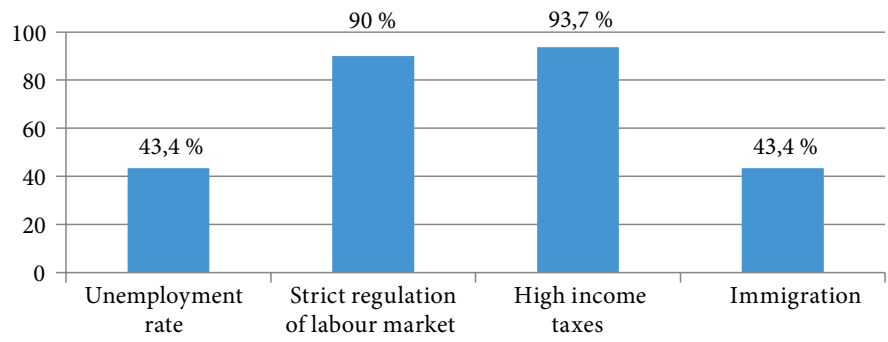

Fig. 2.The factors negatively influencing self-employment duration (percentage of the approving experts)

The results of correlation analysis enabled confirmation of the 3 rd hypothesis proposing that the growth of GDP in transition economies causes the level of self-employment to decrease and self-employment duration to shorten (see Fig. 3). Pearson correlation coefficient showed the negative moderate $\left(\mathrm{r}_{\mathrm{GDP}}=-0.69\right)$ link, meaning that higher GDP level in the country determines smaller number of the self-employed and vice versa (the "push" 3 effect).

3 The "push" effect means that a person chooses self-employment due to the necessity but not due to the opportunities emerged. 


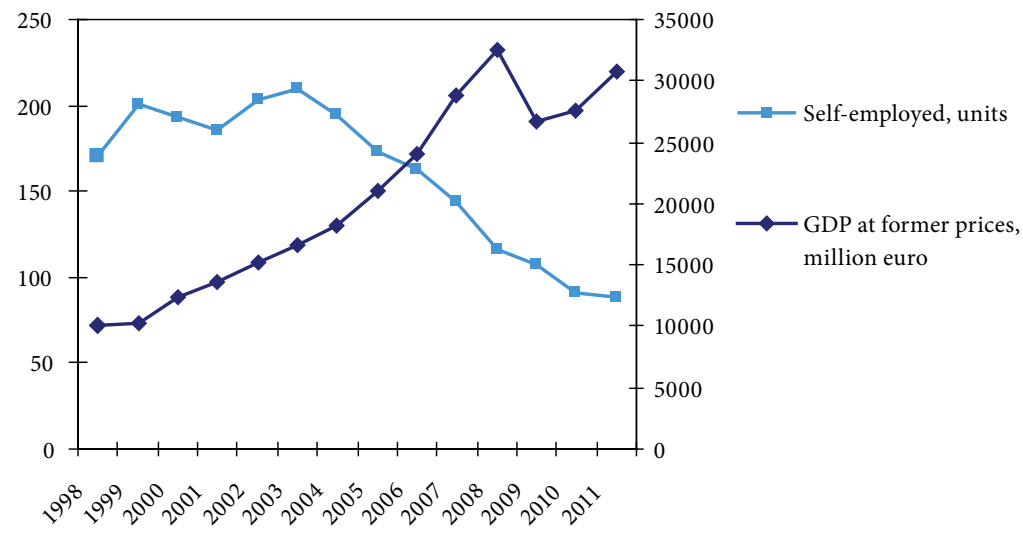

Fig. 3. The dynamics of the number of the self-employed and GDP during the period of 1998-2011 at former prices. $\left(R^{2}=0.7908\right.$, when the time shift is 1 year $)$

In order to establish the impact of growing GDP on self-employment duration, cross correlation coefficient was calculated. Considering the four years' time shift ${ }^{4}$, cross correlation coefficient revealed statistically important negative links between GDP and the number of the self-employed $\left(r_{k}=-0.696\right.$, when the time shift is 0 years; $r_{k}=-0.844$, when the time shift is 1 year, and $r_{k}=-0.601$, when the time shift is 2 years), which proposes that the increase of GDP shortens self-employment duration. The results should be interpreted as follows: year zero or current year means that during the period of 1998-2009, the values of $x$ were compared with the corresponding values of $y$, i.e. how variations of GDP level could influence the level of self-employment in the current year. " +1 " means time shift one year ago, when the values of $x$ during the period of 1998-2008 were compared with the values of $y$ during the period 1999-2009, i.e. how variations of GDP level previous year could influence the level of self-employment the next year. " +2 " means time shift two years ago, when the values of $\mathrm{x}$ during the period 1998-2007 were compared with the values of y during the period 2000-2009, i.e. how variation of GDP level two years before could influence the level of self-employment the later years and so forth. In the researched case, the increasing level of GDP during the period of 1998-2009 could influence the decline of the level of self-employment during the same period; during the periods of 1998-2008 and 1998-2007, the increasing GDP could determine the decline of the level of self-employment during the periods of 1999-2009 and 2000-2009.

With reference to the empirical research, it can be stated that self-employment duration in Lithuania is negatively influenced by high income tax and strict regulation of the labour market. Considering the established negative impact of these factors on self-employment duration, the government of the country could improve the applied self-employment pro-

\footnotetext{
Time shift from 0 to 4 years was chosen because the scope of only 12 years was available during the empirical research. Increasing the time shift, the scope of the researched year was even more reduced (the longer is time interval, the less data can be compared and the less reliable results are obtained).
} 
motion measures. For instance, after the Government of the Republic of Lithuania abolished the privileges applied for the self-employed in 2011, since 2012, the prices of the business licence have returned to the level of 2010, i.e. people wishing to perform any activity under the business licence, have to pay for it 10 times more. The authors of this article are of the opinion that such sudden rise of prices can negatively influence self-employment duration. What is more, self-employment development is restricted by inflexible regulation of the labour market. With reference to the data provided by the Lithuanian Free Market Institute (2012), Lithuania takes the $127^{\text {th }}$ place among 183 states by the flexibility of labour relations, and is the sixth from the end of the list in the EU. At present, the employers are discouraged to hire other people due to inflexible working hours ( 8 hours per day), high redundancy pays, long terms of the notice about the termination of the employment contract, high labour taxes (31 per cent) and other barriers.

Financial business promotion measures, low level of neuroticism and successful previous experience of self-employment were appointed by the experts as the factors having the biggest positive impact on self-employment duration.

Motivating a self-employed person to create work places for other people, the bound of the turnover to start paying the value-added tax could be increased ${ }^{5}$. Other recommendable financial self-employment promotion measure is tax burden (excise, land and other taxes) reduction.

In order to prevent the feeling of neuroticism (ensure good emotional state and increase the feeling of safety) so that self-employment activity would be performed longer, the differences of social guarantees should be reduced because under the present conditions of business environment, the self-employed people have fewer social guarantees in comparison with the employees. At present, the self-employed in Lithuaniaare covered only by the mandatory health insurance and pension insurance (only for the basic pension). The people insured only for the basic pension are not eligible for the sickness benefit, maternity (paternity) allowance or unemployment benefit because they are not covered by these kinds of insurance. What is more, they earn low pension. The self-employed people can insure themselves voluntarily by the state social insurance for the supplementary pension as well as sickness and maternity (paternity) benefits while the employees have all social guarantees for pensions and are eligible for sickness, maternity (paternity), unemployment, accidents at work and occupational disease benefits. By the current procedures, the owners of private companies must pay for the company's liabilities from their personal assets. For instance, the owner of a private company may lose his housing to paybusiness debts in case the other enterprise or authority fails to pay his company, and the company is short of cash.

Meantime, the government pays exclusive attention to the unemployed, but does not consider the people who were previously the self-employed. In our opinion, investing in a person with business experience and the knowledge of business subtleties, the country may save and at the same time increase the level of self-employment. The people who were previously self-employed could be encouraged to start self-employment again, applying financial promotion measures (subsidies, tax privileges).

5 The bound of turnover to start paying the value-added tax is 100000 Litas. The tariff of the value-added tax in Lithuania is 21 per cent. 


\section{Conclusions}

Summarizing, the following conclusions can be made:

1) The established bidirectional - having positive and negative impact - factors of self-employment duration in each group of self-employment factors enable to focus on the selection of the targeted self-employment regulation measures.

2) Using the method of expert evaluation and the statistical methods, the impact of bidirectional factors of self-employment on self-employment duration in the country with transition economy (Lithuania) has been established:

- in the group of the factors of institutional environment, financial and non-financial business promotion measures were indicated by the experts as the factors having positive impact on self-employment duration; self-employment duration is negatively influenced by strictly regulated labour market;

- in the group of the factors of economic environment, self-employment duration is positivelyinfluenced by decreasing GDP while tax tariffs (high income tax) and unemployment rate (during the period of economic decline) have the negative impact on self-employment duration;

- in the group of psychological factors, self-employment duration is positively influenced by extraversion, neuroticism and openness;

- in the group of demographical factors, self-employment duration is positively influenced by education, previous experience of self-employment, younger people and marital status while inability of the immigrants, national minorities and the people of other race to respond quickly to fast-changing business conditions / legal environment has the negative impact on self-employment duration.

\section{References}

Acs, Z. J. 2008. Foundations of high impact entrepreneurship, Foundations and Trends Entrepreneurship 4(6): 535-620. http://dx.doi.org/10.1561/0300000025

Ahn, T. 2009. Racial differences in self-employment exists, Small Business Economics 1-18.

Álvarez-Herranz, A.; Valencia-De-Lara, P.; Pilar Martínez-Ruiz, M. 2011. How entrepreneurial characteristics influence company creation: a cross-national study of 22 countriestested with panel data methodology, Journal of Business Economics and Management 12(3): 529-545. http://dx.doi.org/10.3846/16111699.2011.599409

Andersson, L.; Hammarstedt, M. 2010. Intergenerational transmissions in immigrant self-employment: evidence from three generations, Small Business Economics 34: 261-276. http://dx.doi.org/10.1007/s11187-008-9117-y

Bergmann, H.; Sternberg, R. 2007. The changing face of entrepreneurship in Germany, Small Business Economics 28: 205-221. http://dx.doi.org/10.1007/s11187-006-9016-z

Berzinskiene, D.; Juozaitiene, L. 2011. Impact of labour market measures on unemployment, Inzinerine Ekonomika - Engineering Economics 22(2): 186-195.

Beugelsdijk, S.; Noordehaven, N. 2005. Personality characteristics of self-employed: an empirical study, Small Business Economics 24: 159-167. http://dx.doi.org/10.1007/s11187-003-3806-3 
Blanchflower, D. G. 2008. Minority self-employment in the United States and impact of affirmative action programs, Annals of Finance 5(3): 361-396. http://dx.doi.org/10.1007/s10436-008-0099-1

Briscoe, G.; Dainty, A.; Millett, S. 2000. The impact of tax system on self-employment in British construction industry, International Journal of Manpower 21: 596-613. http://dx.doi.org/10.1108/01437720010379501

Bruce, D. 2000. Effects of the United States tax system on transition into self-employment, Labour Economics 7: 545-574. http://dx.doi.org/10.1016/S0927-5371(00)00013-0

Bruce, D.; Mohsin, M. 2006. Tax policy and entrepreneurship: new time series evidence, Small Business Economics 26: 409-425. http://dx.doi.org/10.1007/s11187-005-5602-8

Borjas, G. 1986. The self-employment experience of immigrants, Journal of Human Resources 21: 485-505. http://dx.doi.org/10.2307/145764

Carrasco, R.; Ejrnæs, M. 2003. Self-employment in Denmark and Spain: institutions, economic conditions and gender differences. CAM, 1-22 [online]. [Cited 12 November 2011]. Available from Internet: www.econ.ku.dk/CAM/Files/workingpapers/2003/2003-06.pdf

Ciavarella, M. A.; Buchholtz, A. K.; Riordan, Ch. M.; Gatewood, R. D.; Stokes, G. S. 2004.The Big Five and venture survival: is there a linkage?, Journal of Business Venturing 19: 465-483.

http://dx.doi.org/10.1016/j.jbusvent.2003.03.001

Ciemleja, G.; Lace, N. 2011. The model of sustainable performance of small and medium-sized enterprise, Inzinerine Ekonomika - Engineering Economics 22(2): 501-509.

Clark, K.; Drinkwater, C. 2010. Patterns of ethnic self-employment in time and space: evidence from British Census microdata, Small Business Economics 34(3): 323-338. http://dx.doi.org/10.1007/s11187-008-9122-1

Congregado, E.; Golpe, A. A.; Carmona, M. 2010. It is a good policy to promote self-employment for job creation? Evidence from Spain, Journal of Policy Modelling 32(6): 828-842. http://dx.doi.org/10.1016/j.jpolmod.2010.09.001

Cowling, M.; Taylor, M. 2001. Entrepreneurial women and men: two different species?, Small Business Economics 16: 167-175. http://dx.doi.org/10.1023/A:1011195516912

Cullen, J. B.; Gordon, R. H. 2002. Taxes and entrepreneurial activity: theory and evidence for the U.S. NBER Working Paper. 9015. p. 58.

Dawson, C.; Henley, A.; Latreille, P. 2009. Why do individuals choose self-employment? Discussion Paper, 3974, 42 [online]. [Cited 12 September 2012]. Available from internet: http:www.ftp.iza.org/dp3974.pdf.

Djankov, S. 2009.The regulation of entry, The World Bank Research Observer 24(2): 183-203. http://dx.doi.org/10.1093/wbro/lkp005

Demirgüc-Kunt, A.; Klapper, L. F.; Panos, G. A. 2007. The origins of self-employment [online]. [Cited 12 March 2012]. Available from internet: http:www.siteresources.worldbank.org/INTFR/Resources/ BosniaFeb07Klapperetal.pdf

Earle, J. S.; Sakova, Z. 2000. Business start-ups or disguised unemployment? Evidence on the character of self-employment from transition economies, Labour Economics 7(5): 575-601. http://dx.doi.org/10.1016/S0927-5371(00)00014-2

European Bank for Reconstruction and Development. 2010. Transition report: recovery and reform [online]. [Cited 09 January 2012]. Available from internet: http:www.ebrd.com/pages/research/publications/flagships/transition.shtml

Evans, D. S.; Leighton, L. S. 1989. The determinants of changes in U.S. self-employment, 1968-1987, Small Business Economics 1: 111-119. http://dx.doi.org/10.1007/BF00398629

Falter, A. M. 2001. Self-employment entry and duration on Switzerland [online]. [Cited 06 February 2011] Available from internet: www.unige.ch /ses/lea/Instituts/oue/Publications/falter-these-paper2.pdf 
Fairlie, R. W.; Meyer, B. D. 2000. Trends in self-employment among white and black men during the twentieth century, The Journal of Human Resources 35(4): 643-669. http://dx.doi.org/10.2307/146366

Galt, V.; Moenning, C. 1996. An analysis of self-employment using UK census of population, International Journal of Entrepreneurial Behavior and Research 2(3): 82-88.

http://dx.doi.org/10.1108/EUM0000000004290

Gentry, W. M.; Hubbard, R. G. 2000. Tax policy and entrepeneurial entry, American Economic Review 90: 283-287. http://dx.doi.org/10.1257/aer.90.2.283

Georgellis, Y.; Sessions, J. G.; Tsitsianis, N. 2005. Self-employment dynamics: a review of the literature, Economics 10(2): 51-84.

Georgellis, Y.; Sessions, J. G.; Tsitsianis, N. 2007. Pecuniary and non-pecuniary aspects of self-employment survival, The Quarterly Review of Economics and Finance 47(1): 94-112. http://dx.doi.org/10.1016/j.qref.2006.03.002

Glocker, D.; Steiner, V. 2007. Self-employment: a way to end unemployment? Empirical evidence from German pseudo-panel data. Discussion Paper Series IZA DP, no. 2561 [online]. [Cited 03 January 2012]. Available from internet: http: / / ftp.iza.org / dp2561.pdf

Goey, F. 2004. Economic structure and self-employment during the twentieth century, in Paper 8th EBHA conference, 16-18 September, Barselona, Spain, 2004, 26 p.

Golpe, A.; Stel, A. 2007. Self-employment and unemployment in spanish regions in the period 1979-2001, Jena Economic Research Papers 2007-021: 1-13.

Grubb, D.; Wells, W. 1993. Employment regulation and patterns of work in EC countries, OECD Economic Studies 21: 7-56.

Henley, A. 2005. Job creation by the self-employed: the roles of the entrepreneurial and financial capital, Small Business Economics 25: 175-196. http://dx.doi.org/10.1007/s11187-004-6480-1

Holtz-Eakin, D.; Joulfain, D.; Rosen, H. S. 1994. Sticking it out: entrepreneurial survival and liquidity constraints, Journal of Political Economy 102: 53-75. http://dx.doi.org/10.1086/261921

Hundley, G. 2006. Family background and the propensity for self-employment, Industrial Relations: A Journal of Economy and Society 45(3): 377-392.

Joona, P. A.; Wadensjö, E. A. 2008. Gender perspective on self-employment entry and performance as self-employed. Discussion Paper Series, no. 3581, 33 p.

Johansson, E. 2000. Determinants of self-employment duration - evidence from Finnish micro-data, Essays on Economics and Business Administration 85: 1-30.

Kangasharju, A.; Pekkala, S. 2002. The role of education in self-employment success in Finland, Growth and Changes 33(2): 216-237. http://dx.doi.org/10.1111/0017-4815.00188

Kim, G. 2007. The analysis of self-employment levels over the life-cycle, The Quarterly Review of Economics and Finance 47(3): 397-410. http://dx.doi.org/10.1016/j.qref.2006.06.004

Koellinger, P. D.; Thurik, A. R. 2009. Entrepreneurship in the business cycle. Tinbergen Institute Discussion Paper, TI09-032 / 3 [online]. [Cited 02 May 2011]. Available from internet: http: www.tinbergen.nl/discussionpapers/09032.pdf

Krasniqi, B. A. 2009. Personal, household and business environmental determinants of entrepreneurship, Journal of Small Business and Enterprise Development 16(1): 146-166. http://dx.doi.org/10.1108/14626000910932935

Knuth, M. 2006. Self-employment and the labour market in Germany [online]. [Cited 20 December 2011]. Available from internet: http:www.resqresearch.org/uploaded_files/publications/knuth10.pdf.

Leoni, T.; Falk, M. 2010. Gender and field of study as determinants of self-employment, Small Business Economics 34: 167-185. http://dx.doi.org/10.1007/s11187-008-9114-1

Moreno, J. J.; Castillo, L. L.; Masere, E. Z. 2010. Firm size and entrepreneurial characteristics: evidence from the SME sector in Argentina, Journal of Business Economics and Management 11(2): 259-282. http://dx.doi.org/10.3846/jbem.2010.13 
Muehlberger, U. 2007. Dependent self-employment. Palgrave Macmillan. http://dx.doi.org/10.1057/9780230288782

Noorderhaven, N. 2004. The role of dissatisfaction and per capita income in explaining self-employment across 15 European countries, Entrepreneurship Theory and Practice 28(5): 447-466. http://dx.doi.org/10.1111/j.1540-6520.2004.00057.x

Oganisjana, K.; Koke, T. 2012. Does competence-oriented higher education lead to students' competitiveness?, Inzinerine Ekonomika - Engineering Economics 23(1): 77-82.

Parker, S. C. 2004. The economics of self-employment and entrepreneurship. Cambridge University Press. http://dx.doi.org/10.1017/CBO9780511493430

Parker, S. C.; Robson, M. T. 2004. Explaining international variation in entrepreneurship: evidence from a panel of OECD countries [online]. [Cited 01 October 2011]. Available from internet: http:www.dur.ac.uk/resources/dbs/businessschool/research\%20paper\%20004.pdf.

Petuskiene, E.; Glinskiene, R. 2011. Entrepreneurship as the basic element for the successful employment of benchmarking and business innovations, Inzinerine Ekonomika - Engineering Economics 22(1): 69-77.

Plougmann, P. 1998. Self-employment in Denmark - trends and policy. Danish Technological Institute \& Centre for Industrial Analysis. 33 p.

Praag, Van M. C. 2003. Business survival and success of young small business owners, Small Business Economics 21(1): 1-17. http://dx.doi.org/10.1023/A:1024453200297

Ritsilä, J.; Tervo, H. 2002. Effects of unemployment on new firm formation: micro-level panel data evidence from Finland, Small Business Economics 19: 31-40. http://dx.doi.org/10.1023/A:1015734424259

Remeikienė, R.; Startienė, G. 2008. Relationship between entrepreneurship and unemployment, in Proceedings, Economics and Management - 2008, 13-osios tarptautinés mokslinés konferencijos pranešimu medžiaga, Kaunas, 643-651 (in Lithuanian).

Remeikiene, R.; Startiene, G. 2011. The institutional environment factors of self-employment in transition economies: the case of Lithuania, in Changes in social and business environment. Proceedings of the $4^{\text {th }}$ International Conference, Panevezys, 186-194.

Remeikiene, R.; Startiene, G.; Vasauskaite, J. 2011. The influence of psychological-sociological factors on self-employment, Economics \& Management, 287-294.

Schuetze, H. J. 2000. Taxes, economic conditions and recent trends in male self-employment: a Canada-US comparison, Labour Econ 7(5): 507-544. http://dx.doi.org/10.1016/S0927-5371(00)00012-9

Singh, G.; DeNoble, A. 2003. View on self-employment and personality: an exploratory study, Journal of Development Entrepreneurship 8(3): 265-281.

Smaliukienè, R.; Bekešienè, S.; Dudzevičiūtè, G. 2012. Counselling for self-employment: the application of decision support system, Business: Theory and Practice 13(1): 18-26.

Snieska, V.; Venckuviene, V. 2011. Hybrid venture capital funds in lithuania: motives, factors and present state of development, Inzinerine Ekonomika - Engineering Economics 22(2): 157-164.

Spencer, J. W.; Gomez, C. 2004. The relationship among national institutional structures, economic factors and domestic entrepreneurial activity: a multi-country study, Journal of Business Research 57: 1098-1107. http://dx.doi.org/10.1016/S0148-2963(03)00040-7

Startiene, G.; Remeikiene, R. 2009. The influence of demographical factors on the interaction between entrepreneurship and unemployment, Inzinerine Ekonomika - Engineering Economics (4): 60-70.

Startiene, G.; Remeikiene, R.; Dumciuviene, D. 2010. Concept of self-employment, Economics and Management 15: 262-274.

Stel, A.; Carree, M.; Thurik, R. 2005. The effect of entrepreneurial activity on national economic growth, Small Business Economics 24(3): 311-321. http://dx.doi.org/10.1007/s11187-005-1996-6 
Stel, van A.; Thurik, R.; Wennekers, S.; Noorderhaven, N. 2003. Self-Employment across 15 European Countries: The role of dissatisfaction [online]. [Cited 16 September 2011]. Available from internet: http:www.entrepreneurship-sme.eu/pdf-ez/N200223.pdf

Taylor, M. P. 1999. Survival of the fittest?, An analysis of self-employment in Britain, The Economic Journal 109(454): 140-155. http://dx.doi.org/10.1111/1468-0297.00422

Tervo, H.; Haapanen, M. 2009. Self-employment duration in urban and rural location, Applied Economics 41(19): 2449-2461. http://dx.doi.org/10.1080/00036840802360278

Thomas, M. K. 2009. The impact of educational histories on the decision to become self-employed: a study of young, aspiring, minority business owners, Small Business Economics 1-12.

Thurik, A. R.; Carree, M. A.; van Stel, A.; Audretsch, D. B. 2008. Does self-employment reduce unemployment?, Journal of Business Venturing 23(6): 673-686. http://dx.doi.org/10.1016/j.jbusvent.2008.01.007

Vázquez-Burgete, J. L.; Lanero, A.; Raisiene, A. G.; García, M. P. 2012. Entrepreneurship education in humanities and social sciences: are students qualified to start a business?, Business: Theory and Practice 13(1): 27-35. http://dx.doi.org/10.3846/btp.2012.03

Verheul, I.; Stel, A.; Thurik, R. 2006. Explaining female and male entrepreneurship at the country level, Entrepreneurship and Regional Development 155-163.

Verheul, I.; Wennekers, S.; Audretsch, D.; Thurik, R. 2001. An eclectic theory of entrepreneurship: policies, institutions and culture, Economic of Science, Technology and Innovation 27: 11-81.

Wagner, J.; Sternberg, R. 2004. Start-up activities, individual characteristics and the regional milieu: lessons for entrepreneurship support policies from German micro data, The Annals of Regional Science 38: 219-240. http://dx.doi.org/10.1007/s00168-004-0193-x

Williams, D. R. 2004. Youth self-employment: it nature and consequences, Small Business Economics 23: 323-336. http://dx.doi.org/10.1023/B:SBEJ.0000032035.30738.01

Wennekers, A. R. M.; Uhlaner, L. M.; Thurik, R. 2002. Entrepreneurship and its conditions: a macro perspective, International Journal of Entrepreneurship Education 1(1): 25-64.

Zhao, H.; Seibert, S. E. 2006. The big five personality dimensions and entrepreneurial status: a meta-analytical review, Journal of Applied Psychology 91(2): 259-271. http://dx.doi.org/10.1037/0021-9010.91.2.259

Gražina STARTIENĖ. Dr, social sciences (economics), professor of Kaunas University of Technology, Department of Economics and International Trade; editor of the journal "Engineering economics" (ISSN 1392-2785) and chief editor of the journal "Economics and Management" (ISSN 1822-6515); co-author of the study "Conditions and presumptions of the increase of Lithuanian business competitiveness" (2011); has published over 50 articles (together with co-authors) during the last 10 years. The main spheres of scientific interests: micro and macro economics, international trade, financing of international trade, international settlement, the risk of exchange rate.

Rita REMEIKIENĖ. During the period of 2007-2011, Rita Remeikienè was a PhD student at Kaunas University of Technology, Faculty of Economics and Management, Department of Economics and International Trade. In 2012, she defended the Thesis "The Factors of Self-employment in Transition Economies" in the sphere of social sciences, economics. Together with co-authors, she has published over 10 articles during the last five years. Her main research interest: entrepreneurship, self-employment, employment. Since 2010, Rita Remeikienè has been working as a lecturer in the Department of Economics and International Trade. 